\title{
Glaciecola nitratireducens sp. nov., isolated from seawater
}

\author{
Keun Sik Baik, ${ }_{1}^{1}$ Yoon-Dong Park, ${ }^{2}$ Chi Nam Seong, ${ }^{1}$ Eun Mi Kim, ${ }^{1,3}$ \\ Kyung Sook $\mathrm{Bae}^{4}$ and Jongsik Chun ${ }^{2}$ \\ ${ }^{1}$ Department of Biology, College of Natural Sciences, Sunchon National University, Sunchon \\ 540-742, Republic of Korea \\ ${ }^{2}$ School of Biological Sciences and Institute of Microbiology, Seoul National University, NS70, \\ 56-1 Shillim-dong, Kwanak-gu, Seoul 151-742, Republic of Korea \\ ${ }^{3}$ Department of Dental Hygiene, Kwangyang Health College, Kwangyang 545-703, Republic of \\ Korea \\ ${ }^{4}$ Korea Research Institute of Bioscience and Biotechnology, Yusung PO Box 115, Taejon \\ 305-600, Republic of Korea
}

Correspondence Jongsik Chun jchun@snu.ac.kr

\begin{abstract}
A marine bacterial strain, FR1064 ${ }^{\top}$, was isolated from a surface seawater sample collected off Jeju Island, South Korea. Phylogenetic analysis based on 16S rRNA gene sequences indicated that the isolate belonged to the Gammaproteobacteria and was related to the genus Glaciecola with $97 \cdot 6 \%$ sequence similarity to Glaciecola pallidula, its nearest phylogenetic neighbour. DNA-DNA relatedness between strain FR $1064^{\top}$ and G. pallidula ACAM $615^{\top}$ was $55 \%$. Cells of the novel isolate were Gram-negative, aerobic, rod-shaped, motile and halophilic, with an optimum sea salts concentration of $4-7 \%$. The major fatty acids were straight-chain saturated $\left(C_{16: 0}\right)$, summed feature 3 and monounsaturated fatty acid $C_{18: 1}$. The DNA $G+C$ content was $44 \mathrm{~mol} \%$. Several phenotypic characteristics differentiated the novel isolate from all previously described members of the genus Glaciecola. The polyphasic data obtained in this study clearly demonstrate that strain FR $1064^{\top}$ represents a novel species of the genus Glaciecola. The name Glaciecola nitratireducens sp. nov. is therefore proposed, with strain FR1064 ${ }^{\top}\left(=\right.$ KCTC $\left.12276^{\top}=J C M 12485^{\top}\right)$ as the type strain.
\end{abstract}

The genus Glaciecola was originally created to accommodate aerobic, psychrophilic, halophilic bacteria and initially comprised two species, Glaciecola punicea and Glaciecola pallidula. These species were isolated from sea-ice diatom assemblage samples collected from coastal areas of eastern Antarctica (Bowman et al., 1998). Recently, two further species of the genus, namely Glaciecola mesophila and Glaciecola polaris, have been described, isolated from marine invertebrate specimens and Arctic Ocean seawater, respectively (Romanenko et al., 2003; Van Trappen et al., 2004). In the course of our study on marine microbial diversity, a Glaciecola-like strain, designated strain FR1064 ${ }^{\mathrm{T}}$, was isolated from surface seawater and was the subject of a comprehensive taxonomic investigation. In this study, the polyphasic taxonomic properties of strain FR1064 ${ }^{\mathrm{T}}$ are presented.

Strain FR1064 ${ }^{\mathrm{T}}$ was isolated from a coastal surface seawater sample collected off Jeju Island, Republic of Korea. The

The GenBank/EMBL/DDBJ accession number for the $16 \mathrm{~S}$ rRNA gene sequence of strain FR1064 ${ }^{\top}$ is $A Y 787042$. sample was diluted with sterilized artificial seawater (ASW; Lyman \& Fleming, 1940), spread onto a plate containing marine agar 2216 (MA; Difco) and incubated at $25^{\circ} \mathrm{C}$ for 3 weeks. The isolate was routinely cultured on MA and maintained as a glycerol suspension $\left(20 \%\right.$, w/v) at $-80{ }^{\circ} \mathrm{C}$. G. pallidula ACAM $615^{\mathrm{T}}$, cultured on MA at $15^{\circ} \mathrm{C}$, was used as a reference strain.

Bacterial DNA preparation, PCR amplification and sequencing of the 16S rRNA gene were carried out as described previously (Chun \& Goodfellow, 1995). The resulting gene sequence of strain FR1064 ${ }^{\mathrm{T}}$ was aligned manually against sequences obtained from GenBank. Phylogenetic trees were inferred from the regions available for all sequences (positions 28-1433; Escherichia coli numbering system) using the Fitch-Margoliash (Fitch \& Margoliash, 1967), maximum-likelihood (Felsenstein, 1981), maximum-parsimony (Fitch, 1971) and neighbour-joining (Saitou \& Nei, 1987) methods. Evolutionary distance matrices were generated according to Jukes \& Cantor (1969). The resultant tree topologies were evaluated in bootstrap analyses (Felsenstein, 1985) of the neighbour-joining methods 
based on 1000 resamplings. The alignment and phylogenetic analyses were carried out using the jPHYDIT program (Jeon et al., 2005; http://chunlab.snu.ac.kr/jphydit) and PAUP 4.0 (Swofford, 1998) as described previously (Kim et al., 2005; Yi \& Chun, 2006).

Preliminary sequence comparisons with the 16S rRNA gene sequences held in GenBank indicated that the novel isolate belonged to the class Gammaproteobacteria. The resultant sequence was then aligned manually based on 16S rRNA secondary structure (Gutell, 1994) with representative sequences of the Gammaproteobacteria obtained from GenBank. Strain FR1064 ${ }^{\mathrm{T}}$ showed the highest $16 \mathrm{~S}$ rRNA gene sequence similarity to G. pallidula ACAM $615^{\mathrm{T}}$ (97.6\%), followed by G. polaris LMG $21857^{\mathrm{T}}(95 \cdot 4 \%)$, G. mesophila LMG $21855^{\mathrm{T}}(95 \cdot 2 \%)$ and G. punicea ACAM $611^{\mathrm{T}}(94 \cdot 2 \%)$. To elucidate the phylogenetic relationship between the novel isolate and the other species of the genus Glaciecola, phylogenetic trees were constructed using four different tree-making algorithms. The neighbour-joining tree (Fig. 1) showed that strain FR1064 ${ }^{\mathrm{T}}$ formed a monophyletic clade with G. pallidula ACAM $615^{\mathrm{T}}$ with $100 \%$ bootstrap support. This relationship was confirmed by all other tree-inferring methods used in this study.

The taxonomic relationship between strain FR $1064^{\mathrm{T}}$ and $G$. pallidula ACAM $615^{\mathrm{T}}$ was further examined using DNADNA hybridization. Genomic relatedness was determined using a membrane filter technique (Seldin \& Dubnau, 1985) using a DIG High Prime DNA labelling and detection starter kit II (Roche). When DNAs were used individually as labelled DNA probes for reciprocal hybridization experiments and conducted in duplicate, the DNA-DNA relatedness value between strain FR1064 ${ }^{\mathrm{T}}$ and G. pallidula ACAM
$615^{\mathrm{T}}$ was $55 \%$. It is clear from $16 \mathrm{~S}$ rRNA gene sequence and DNA-DNA hybridization data that strain FR $1064^{\mathrm{T}}$ represents a novel species in the genus Glaciecola (Wayne et al., 1987).

For phenotypic characterization, strain FR $1064^{\mathrm{T}}$ was grown on $\mathrm{MA}$ at $25^{\circ} \mathrm{C}$ unless otherwise specified. Cellular morphology was observed by differential interference microscopy (Axioskop 40; Zeiss) and scanning electron microscopy (JSM-6400; JEOL) using cells grown at $25^{\circ} \mathrm{C}$ for 3 days. Motility was examined using wet mounts. Growth under anaerobic conditions was checked in an anaerobic chamber $\left(\mathrm{CO}_{2} / \mathrm{H}_{2} / \mathrm{N}_{2}, 10: 10: 80\right.$; Sheldon Manufacturing). The $\mathrm{pH}$ range $(\mathrm{pH} 4-12)$ for growth was determined using MA. The requirement for sea salts (0-11\%, Sigma) for growth was tested using synthetic ZoBell medium (ZoBell, 1941; 15 g Bacto agar, 5 g Bacto peptone, 1 g yeast extract, $0 \cdot 1 \mathrm{~g}$ ferric citrate in 11 distilled water). Growth at various temperatures was examined on MA at $4-50^{\circ} \mathrm{C}$. Biochemical tests were performed using the API 20E, API 20NE and API ZYM kits (bioMérieux). Strips were inoculated with a heavy bacterial suspension in ASW or AUX medium (bioMérieux) supplemented with $2 \%(\mathrm{w} / \mathrm{v})$ sea salts. Catalase and oxidase activities were determined using $3 \%(\mathrm{v} / \mathrm{v})$ hydrogen peroxide and Kovacs' reagent (Kovacs, 1956), respectively. The novel isolate is halophilic as it required $2-9 \%(\mathrm{w} / \mathrm{v})$ artificial sea salts for growth (optimum 4-7\%). The results of biochemical and physiological tests are given in the species description and Table 1.

Cellular fatty acids of the novel isolate were analysed as methyl esters by GLC by the MIDI system according to the manufacturer's instructions. Fatty acid methyl esters were prepared from biomass grown on $\mathrm{MA}$ at $25^{\circ} \mathrm{C}$ for 2 days.
$0 \cdot 1$

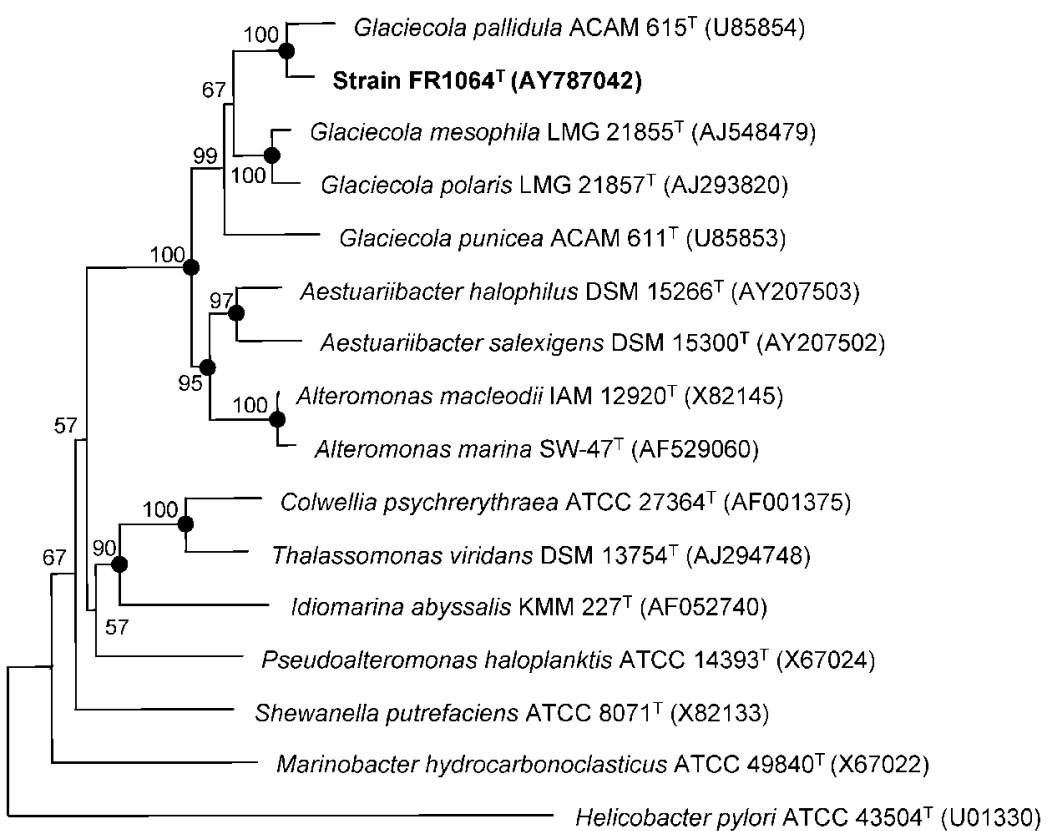

Fig. 1. Neighbour-joining phylogenetic tree based on nearly complete 16S rRNA gene sequences showing relationships between strain FR $1064^{\top}$ and members of the class Gammaproteobacteria. Bootstrap values, expressed as percentages of 1000 replications, are given at the nodes. Solid circles indicate that the corresponding nodes were also recovered in Fitch-Margoliash, maximum-likelihood and maximum-parsimony trees. Helicobacter pylori ATCC $43504^{\mathrm{T}}$ was used as an outgroup. Bar, 0.1 nucleotide substitutions per position. 
Table 1. Phenotypic characteristics that differentiate strain $F R 1064^{\top}$ from its nearest phylogenetic neighbours

Species: 1, FR1064 $4^{\mathrm{T}}$; 2, Glaciecola polaris LMG 21857 ; 3, G. mesophila LMG $21855^{\mathrm{T}}$; 4, G. punicea ACAM 611 ; 5, G. pallidula ACAM $615^{\mathrm{T}}$. Data from Bowman et al. (1998), Romanenko et al. (2003), Van Trappen et al. (2004) and this study. +, Positive; -, negative; W, weakly positive; ND, not determined.

\begin{tabular}{|c|c|c|c|c|c|}
\hline Characteristic & 1 & 2 & 3 & 4 & 5 \\
\hline Temperature range for growth $\left({ }^{\circ} \mathrm{C}\right)$ & $15-30$ & $5-30$ & $7-35$ & $-2-25$ & $-2-20$ \\
\hline 0 and $4{ }^{\circ} \mathrm{C}$ & - & - & - & + & + \\
\hline $7^{\circ} \mathrm{C}$ & - & + & + & + & + \\
\hline $25^{\circ} \mathrm{C}$ & + & + & + & + & - \\
\hline Nitrate reduction & + & - & - & - & - \\
\hline Acid production from glucose & - & - & $\mathrm{W}$ & $\mathrm{W}$ & $\mathrm{W}$ \\
\hline \multicolumn{6}{|l|}{ Hydrolysis of: } \\
\hline Aesculin & - & + & $\mathrm{W}$ & + & - \\
\hline Gelatin & + & + & - & - & - \\
\hline Gluconate & $\mathrm{W}$ & $\mathrm{ND}$ & - & - & - \\
\hline Glucose & - & - & + & - & - \\
\hline Malate & - & - & - & + & - \\
\hline Maltose & + & + & + & - & - \\
\hline Mannitol & - & + & + & - & - \\
\hline Mannose & + & + & $\mathrm{W}$ & - & - \\
\hline Sucrose & - & + & + & - & - \\
\hline \multicolumn{6}{|l|}{ Enzyme activities (API ZYM): } \\
\hline$\alpha$-Galactosidase & - & $\mathrm{w}$ & + & + & + \\
\hline$\beta$-Galactosidase & - & + & + & + & + \\
\hline DNA G $+C$ content $(\mathrm{mol} \%)$ & 44 & 44 & 44 & $44-46$ & 44 \\
\hline
\end{tabular}

DNA G + C content (mol\%) was determined by the thermal denaturation method of Marmur \& Doty (1962). The DNA $\mathrm{G}+\mathrm{C}$ content for strain FR $1064^{\mathrm{T}}$ was $44 \mathrm{~mol} \%$ and the cellular fatty acid profile is given in Table 2 .

On the basis of phylogenetic analysis and DNA-DNA hybridization, it is evident that strain FR1064 ${ }^{\mathrm{T}}$ should be assigned as representing a novel species of the genus Glaciecola. In addition, a number of physiological and chemotaxonomic characteristics clearly distinguish the novel isolate from other phylogenetically related species (Tables 1 and 2). Therefore, we propose that strain FR1064 ${ }^{\mathrm{T}}$ be classified as a representative of a novel species within the genus Glaciecola, for which the name Glaciecola nitratireducens sp. nov. is proposed.

\section{Description of Glaciecola nitratireducens sp. nov.}

Glaciecola nitratireducens (ni.tra.ti.re.du'cens. N.L. n. nitras nitrate; L. part. adj. reducens converting to a different state; N.L. part. adj. nitratireducens reducing nitrate).
Gram-negative, aerobic and halophilic. Catalase-positive. Colonies on MA are circular, convex with an entire margin, slightly cream-coloured and approximately $1.5 \mathrm{~mm}$ in diameter after 5 days at $25^{\circ} \mathrm{C}$. Cells are motile, oval- or rod-shaped and $0.5-0.6 \times 1.0-1.5 \mu \mathrm{m}$. Spores are not formed. Does not grow without sea salts. Growth occurs in $2-9 \%(\mathrm{w} / \mathrm{v})$ sea salts (optimum of $4-7 \%)$. Growth occurs at $\mathrm{pH}$ 6-9 (optimum $\mathrm{pH}$ of 8 ) and at temperatures between 15 and $30^{\circ} \mathrm{C}$ (optimum of $25^{\circ} \mathrm{C}$ ). Does not utilize citrate, caprate, adipate or phenylacetate. Produces cytochrome oxidase, but not ornithine decarboxylase, arginine dihydrolase, lysine decarboxylase, urease, indole, acetoin, $\mathrm{H}_{2} \mathrm{~S}$ or tryptophan deaminase. Negative in tests for the fermentation of inositol, sorbitol, rhamnose, melibiose and amygdalin. Produces alkaline phosphatase, esterase (C4), esterase lipase (C8), leucine arylamidase, acid phosphatase, naphtholAS-BI-phosphohydrolase and trypsin, but not lipase (C14), valine arylamidase, cystine arylamidase, $\alpha$-chymotrypsin, $\beta$ glucuronidase, $\alpha$-glucosidase, $N$-acetyl- $\beta$-glucosaminidase, $\beta$-glucosidase, $\alpha$-mannosidase or $\alpha$-fucosidase. Other physiological and biochemical characteristics are given in Table 1 . Major fatty acids are summed feature $3(38 \cdot 2 \%)$, 
Table 2. Cellular fatty acid content (\%) of strain FR1064 and Glaciecola species

Strains: 1, FR $1064^{\mathrm{T}}$; 2, G. polaris LMG $21857^{\mathrm{T}}$; 3, G. mesophila LMG $21855^{\mathrm{T}}$; 4, G. punicea ACAM $611^{\mathrm{T}}$; 5, G. pallidula ACAM $615^{\mathrm{T}}$. Data from Bowman et al. (1998), Romanenko et al. (2003), Trappen et al. (2004) and this study. Values are percentages of total fatty acids. ND, Not detected; $\operatorname{tr},<1 \cdot 0 \%$.

\begin{tabular}{|c|c|c|c|c|c|}
\hline Fatty acid & 1 & 2 & 3 & 4 & 5 \\
\hline \multicolumn{6}{|l|}{ Saturated fatty acids: } \\
\hline $\mathrm{C}_{12: 0}$ & $1 \cdot 6$ & $3 \cdot 1$ & $2 \cdot 6$ & $\mathrm{ND}$ & ND \\
\hline $\mathrm{C}_{14: 0}$ & $7 \cdot 0$ & $4 \cdot 1$ & $1 \cdot 2$ & $1 \cdot 2$ & $3 \cdot 6$ \\
\hline $\mathrm{C}_{15: 0}$ & $1 \cdot 0$ & $2 \cdot 0$ & $\operatorname{tr}$ & $1 \cdot 0$ & $1 \cdot 6$ \\
\hline $\mathrm{C}_{16: 0}$ & $20 \cdot 5$ & $23 \cdot 3$ & $33 \cdot 0$ & $10 \cdot 0$ & $9 \cdot 4$ \\
\hline $\mathrm{C}_{17: 0}$ & $1 \cdot 5$ & ND & $2 \cdot 1$ & $\operatorname{tr}$ & $1 \cdot 3$ \\
\hline $\mathrm{C}_{18: 0}$ & $1 \cdot 9$ & ND & $1 \cdot 9$ & $\operatorname{tr}$ & $\operatorname{tr}$ \\
\hline \multicolumn{6}{|l|}{ Branched fatty acids: } \\
\hline iso- $\mathrm{C}_{16: 0}$ & $1 \cdot 0$ & ND & $2 \cdot 3$ & $1 \cdot 8$ & $2 \cdot 5$ \\
\hline anteiso- $\mathrm{C}_{17: 0}$ & $\operatorname{tr}$ & ND & $2 \cdot 0$ & ND & ND \\
\hline \multicolumn{6}{|l|}{ Unsaturated fatty acids: } \\
\hline $\mathrm{C}_{14: 1} \omega 7 c$ & ND & ND & $\operatorname{tr}$ & $\operatorname{tr}$ & $3 \cdot 7$ \\
\hline $\mathrm{C}_{15: 1} \omega 8 c$ & $\operatorname{tr}$ & $\mathrm{ND}$ & $\operatorname{tr}$ & $\operatorname{tr}$ & $3 \cdot 4$ \\
\hline $\mathrm{C}_{17: 1} \omega 8 c$ & $2 \cdot 6$ & $2 \cdot 6$ & $3 \cdot 2$ & $4 \cdot 6$ & $5 \cdot 0$ \\
\hline $\mathrm{C}_{18: 1} \omega 7 c$ & $7 \cdot 7$ & $4 \cdot 8$ & $5 \cdot 2$ & $16 \cdot 3$ & $12 \cdot 6$ \\
\hline $\mathrm{C}_{18: 1} \omega 9 c$ & $\operatorname{tr}$ & ND & $\operatorname{tr}$ & $\operatorname{tr}$ & $\operatorname{tr}$ \\
\hline \multicolumn{6}{|l|}{ Hydroxy fatty acids: } \\
\hline $\mathrm{C}_{12: 0} 3-\mathrm{OH}$ & $2 \cdot 8$ & $5 \cdot 5$ & $\operatorname{tr}$ & $\mathrm{ND}$ & ND \\
\hline $\mathrm{C}_{16: 0} 2-\mathrm{OH}$ & ND & $1 \cdot 7$ & ND & $\mathrm{ND}$ & ND \\
\hline $\mathrm{C}_{16: 1} 2-\mathrm{OH}$ & ND & $2 \cdot 0$ & $\mathrm{ND}$ & $\mathrm{ND}$ & ND \\
\hline \multicolumn{6}{|l|}{ Methyl fatty acids: } \\
\hline $\mathrm{C}_{18: 0}$ 10-methyl & ND & $1 \cdot 4$ & $\mathrm{ND}$ & $\mathrm{ND}$ & ND \\
\hline $\mathrm{C}_{18: 1} \omega 7 c$ 11-methyl & $1 \cdot 4$ & ND & ND & $\mathrm{ND}$ & ND \\
\hline Summed feature $3^{\star}$ & $38 \cdot 2$ & $41 \cdot 7$ & $43 \cdot 0$ & $60 \cdot 7$ & $54 \cdot 2$ \\
\hline Unknown fatty acid 11.799 (ECL) & $4 \cdot 2$ & ND & $\mathrm{ND}$ & $\mathrm{ND}$ & ND \\
\hline
\end{tabular}

* Summed features represent groups of two or three fatty acids that could not be separated by GLC with the MIDI system. Summed feature 3 contained iso- $\mathrm{C}_{15: 0} 2-\mathrm{OH}$ and/or $\mathrm{C}_{16: 1} \omega 7 c$.

$\mathrm{C}_{16: 0}(20 \cdot 5 \%), \mathrm{C}_{18: 1} \omega 7 c(7 \cdot 7 \%)$ and $\mathrm{C}_{14: 0}(7 \cdot 0 \%)$. The DNA G $+C$ content of the type strain is $44 \mathrm{~mol} \%$.

The type strain, FR $1064^{\mathrm{T}}\left(=\mathrm{KCTC} 12276^{\mathrm{T}}=\mathrm{JCM} 12485^{\mathrm{T}}\right)$, was isolated from seawater off Jeju Island, Republic of Korea.

\section{Acknowledgements}

We thank Dr John Bowman (Australian Food Safety Centre of Excellence) for the gift of the type strain of Glaciecola pallidula. This work was supported, in part, by Korea Ministry of Science and Technology under National Research Laboratory Program (M10500000110-05J0000-11010) and 21C Frontier Microbial Genomics and Applications Center Program (MG05-0101-2-0).

\section{References}

Bowman, J. P., McCammon, S. A., Brown, J. L. \& McMeekin, T. A. (1998). Glaciecola punicea gen. nov., sp. nov. and Glaciecola pallidula gen. nov., sp. nov.: psychrophilic bacteria from Antarctic sea-ice habitats. Int J Syst Bacteriol 48, 1213-1222.

Chun, J. \& Goodfellow, M. (1995). A phylogenetic analysis of the genus Nocardia with 16S rRNA gene sequences. Int J Syst Bacteriol 45, 240-245.

Felsenstein, J. (1981). Evolutionary trees from DNA sequences: a maximum likelihood approach. J Mol Evol 17, 368-376.

Felsenstein, J. (1985). Confidence limits on phylogenies: an approach using the bootstrap. Evolution 39, 783-791.

Fitch, W. M. (1971). Toward defining the course of evolution: minimum change for a specific tree topology. Syst Zool 20, 406-416.

Fitch, W. M. \& Margoliash, E. (1967). Construction of phylogenetic trees. Science 155, 279-284.

Gutell, R. R. (1994). Collection of small subunit (16S- and 16S-like) ribosomal RNA structures: 1994. Nucleic Acids Res 22, 3502-3507.

Jeon, Y.-S., Chung, H., Park, S., Hur, I., Lee, J.-H. \& Chun, J. (2005). jPHYDIT: a JAVA-based integrated environment for molecular phylogeny of ribosomal RNA sequences. Bioinformatics 21, 3171-3173.

Jukes, T. H. \& Cantor, C. R. (1969). Evolution of protein molecules. In Mammalian Protein Metabolism, vol. 3, pp. 21-132. Edited by H. N. Munro. New York: Academic Press.

Kim, B. S., Oh, H. M., Kang, H. \& Chun, J. (2005). Archaeal diversity in tidal flat sediment as revealed by $16 \mathrm{~S}$ rDNA analysis. $J$ Microbiol 43, 144-151.

Kovacs, N. (1956). Identification of Pseudomonas pyocyanea by the oxidase reaction. Nature 178, 703.

Lyman, J. \& Fleming, R. H. (1940). Composition of sea water. J Mar Res 3, 134-146.

Marmur, J. \& Doty, P. (1962). Determination of the base composition of deoxyribonucleic acid from its thermal denaturation temperature. J Mol Biol 5, 109-118.

Romanenko, L. A., Zhukova, N. V., Rohde, M., Lysenko, A. M., Mikhailov, V. V. \& Stackebrandt, E. (2003). Glaciecola mesophila sp. nov., a novel marine agar-digesting bacterium. Int J Syst Evol Microbiol 53, 647-651.

Saitou, N. \& Nei, M. (1987). The neighbor-joining method: a new method for reconstructing phylogenetic trees. Mol Biol Evol 4, 406-425.

Seldin, L. \& Dubnau, D. (1985). Deoxyribonucleic acid homology among Bacillus polymyxa, Bacillus macerans, Bacillus azotofixans, and other nitrogen-fixing Bacillus strains. Int J Syst Bacteriol 35, 151-154.

Swofford, D. L. (1998). PAUP*: Phylogenetic analysis using parsimony ( ${ }^{*}$ and other methods), version 4 . Sunderland, MA: Sinauer Associates.

Van Trappen, S. V., Tan, T. L., Yang, J., Mergaert, J. \& Swings, J. (2004). Glaciecola polaris sp. nov., a novel budding and prosthecate bacterium from the Arctic Ocean, and emended description of the genus Glaciecola. Int J Syst Evol Microbiol 54, 1765-1771.

Wayne, L. G., Brenner, D. J., Colwell, R. R. \& 9 other authors (1987). International Committee on Systematic Bacteriology. Report of the ad hoc committee on reconciliation of approaches to bacterial systematics. Int J Syst Bacteriol 37, 463-464.

Yi, H. \& Chun, J. (2006). Thalassobius aestuarii sp. nov., isolated from tidal flat sediment. J Microbiol 44, 171-176.

Zobell, C. E. (1941). Studies on marine bacteria. I. The cultural requirements of heterotrophic aerobes. J Mar Res 4, 42-75. 